\title{
Effects of Therapeutic Massage and Home Exercise Program on Pain, Range of Motion, Depression, and Quality of Life after Arthroscopic Rotator Cuff Repair
}

\author{
Young-Min Lee', Jung-Won Kwon² \\ 'Department of Health, Graduate School, Dankook University, Cheonan, Republic of Korea; ${ }^{2}$ Department of Physical Therapy, College of Health \\ Sciences, Dankook University, Cheonan, Republic of Korea
}

Purpose: This study examined the effects of therapeutic massage (TMP) and home exercise program (HEP) on pain, range of motion (ROM), depression, and quality of life (QOL) after arthroscopic rotator cuff repair in middle-aged women.

Methods: Nineteen middle-aged women who underwent arthroscopic rotator cuff repair were enrolled in the study. All subjects were assigned randomly to the experimental group $(n=9)$ or the control group $(n=10)$. The subjects in both groups performed HEP for 30 minutes, three times per day, for eight weeks. The subjects in the experimental group also performed HEP, with TMP being performed for 30 minutes, 16 sessions for eight weeks. All subjects were evaluated with a visual analogue scale (VAS), shoulder ROM, self-rating depression scale (SDS), and Korean brief version of WHO quality of life scale (WHOQOL-BREF). A paired t-test was performed to test the significant differences between before and after the intervention. An independent t-test was conducted to test the significant differences between the groups.

Results: Following the intervention, both groups showed significant differences than before the intervention in the VAS, shoulder ROM, SDS, and WHOQOL-BREF $(p<0.05)$. There were significant differences in the ROM of shoulder flexion, SDS, and WHOQOL-BREF between the groups $(p<0.05)$.

Conclusion: These findings suggest that intensive TMP is an effective method for improving shoulder flexion mobility, depressive symptom, and QOL in middle-aged women after arthroscopic rotator cuff repair.

Keywords: Therapeutic massage, Home exercise program, Depression, Quality of life, Rotator cuff repair

\section{서 론}

어깨 돌림근띠 손상은 노령 인구 및 스포츠 인구의 증가로 중장년층 에서 높은 빈도로 관찰되고 있으며, 특히 중년 여성은 남성에 비해 근 육량과 근력의 감소가 빠르게 나타나고 상대적인 가사노동 증가로 인해 발병률이 증가하고 있는 추세이다. 어깨 돌림근띠 파열은 가시 위근, 가시아래근, 작은원근, 어깨밑근의 힘줄이 부분 혹은 완전 파열 되는 것으로 기능적인 부분에서는 40 세 이후부터 증가하기 시작하 며, ${ }^{1}$ 특히 50세 이상에서 전층 돌림근띠 파열의 유병률은 20-25\%로 나이가 들수록 증가하고 있다. ${ }^{2}$ 어깨 돌림근띠 손상 환자들의 기전은 명확하지 않으나 특이적으로 야간에 극심한 통증을 호소하며, 이러 한 증상이 적절하게 개선되지 않으면 만성 통증으로 진행되어 어깨
관절의 가동범위 감소, 일상생활활동의 기능적 어려움, 우울 및 불안, 수면장애, 삶의 질 저하를 초래할 수 있다. ${ }^{3}$

어깨 돌림근띠 파열의 치료는 임상적 증상 및 파열의 정도에 따라 비수술적 치료와 수술적 치료로 구분된다. 일반적으로 비수술적인 치료는 물리치료와 약물요법 그리고 증상을 유발시킬 수 있는 생활 양식의 변화 등이 있지만 통증이 4-6개월 지속되거나 기능적 활동의 호전이 없다면 수술적 치료가 고려된다. 한국 건강보험심사평가원 자료에 따르면 최근 우리나라의 어깨 돌림근띠 파열 환자 수가 증가 한 것에 비례하여 수술 빈도가 2007년 6,771건에서 2015년 74,120건으

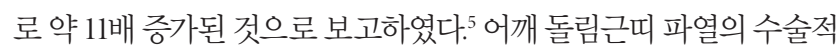
치료인 관절경 돌림근띠 복원술은 파열된 힘줄과 빼의 결합을 최대 화하고 본래의 해부학적 구조를 복원시키면서 힘줄의 긴장성을 낮추
Received Mar 11, 2021 Revised Mar 19, 2021

Accepted Apr 6, 2021

Corresponding author Jung-Won Kwon

E-mail kjwonpt@hanmail.net
Copylight ( 2021 The Korean Society of Physical Therapy

This is an Open Access article distribute under the terms of the Creative Commons Attribution Non-commercial License (https:// creativecommons.org/license/by-nc/4.0.) which permits unrestricted non-commercial use, distribution, and reproduction in any medium, provided the original work is properly cited. 
기 위해 시행하며, 수술 절개 부위가 작아 근육과 같은 연부조직 손 상이 적고 수술 후 통증이 적어 빠른 재활 및 기능회복이 가능하다 는 이점이 있다. ${ }^{6}$ 하지만 수술 후 빠른 석회화 진행으로 인해 관절이 쉽게 경화되고 유착되는 특징, 어깨관절의 강직을 동반한 심한 통증 과 같은 이차적인 합병증이 발생될 수 있어 적절한 통증 조절을 통해 환자가 조기에 재활 운동을 할 수 있도록 유착, 피막수축현상, 근육 의 약화와 관절주위의 연부조직 경화를 예방하는 치료적 중재를 시 행해야한다.

최근에는 수술의 성공률을 높이기 위해 수술 후 기능적 회복을 위 한 치료적 중재들이 중요한 역할을 한다는 인식이 높아짐에 따라 관 절경 돌림근띠 수술 후 환자의 기능적 회복을 향상시키기 위한 다양 한 중재 방법에 대한 관심이 높아지고 있다. ${ }^{8}$ 치료적 마사지는 조직의 유착과 통증을 감소시키고 관절가동범위의 증가 및 혈액순환을 증 가시키며 신경계와 근육계의 흥분을 줄여 이완되도록 한다. $\mathrm{Kim}^{9}$ 은 어깨관절 손상 환자에게 적용한 치료적 마사지가 어깨관절의 통증 감소 및 관절가동범위 증가에 효과적이었다고 보고하였으며, $\mathrm{Ham}^{10}$ 은 무릎관절 전치환술 환자에게 치료적 마사지를 적용하여 통증 개 선과 관절가동범위에 효과가 있다고 보고하였다. 또한, 관절경 수술 후 대표적인 가정운동프로그램으로 사용되는 저강도의 자가-스트 레칭은 어깨관절 손상 환자의 독립적인 일상생활활동을 회복하기 위해 필수적으로 적용하며 시설과 공간의 제한 없이 쉽게 적용할 수 있는 이점이 있다고 하였다."1 Shin과 Lee ${ }^{12}$ 는 만성적 어깨관절 질환을 가진 중년 여성을 대상으로 스트레칭 운동 프로그램을 적용한 결과 통증 및 관절가동범위의 개선과 악력의 증가가 나타났다고 보고하 였으며, Yoon ${ }^{13}$ 은 관절경 수술 후 통증 완화와 관절가동범위의 개선 및 근력 회복을 위해 안정화 운동과 규칙적인 저강도 스트레칭이 필 요하다고보고하였다.

어깨 돌림근띠 파열은 관절가동범위의 제한과 같은 기능적인 문 제 외에도 야간통과 함께 우울, 불안, 수면, 삶의 질 저하 등의 심리적 인 문제가 발생할 수 있으며, 활동적 제한은 우울 증상과 삶의 질에 영향을 줄 수 있다고 한다..$^{14} \mathrm{Jeon}^{15}$ 은 포괄적 자세 재교육 스트레칭과 분절 스트레칭이 어깨 통증과 어깨통증장애지수 그리고 삶의 질에 영향을 줄 수 있다고 하였으며, $\mathrm{Kwak}^{16}$ 은 유착성 관절낭염 환자에게 도수치료와 가정운동프로그램이 환자의 어깨 기능뿐만 아니라 삶의 질에도 효과적이라고 보고하였다. 이처럼 많은 선행 연구들에서 어 깨관절 수술 후 치료적 중재를 통한 근기능 회복과 관절가동범위 개 선에 대해 연구하였다. 하지만 최근 근골격계 질환의 평가와 치료에 있어 심리적, 사회적 요소가 포함된 우울이나 삶의 질이 중요한 요소 로 생각되고 있음에도 불구하고 어깨 돌림근띠 봉합술 환자의 수술 후 우울과 삶의 질을 함께 제시한 연구는 미흡한 실정이다. 또한 중년 여성의 경우, 폐경과 노화로 인한 신체적 변화로 인해 우울이나 불안
등의 심리적 변화가 더욱 두드러지며 어깨 돌림근띠 파열과 같은 질 환이나 증상의 상태에 동반하여 우울증이 심해지고 삶의 질이 저하 되기 쉽다.

따라서 본 연구에서는 어깨 돌림근띠 복원술을 시행한 중년 여성 을 대상으로 8 주 동안 치료적 마사지와 가정운동프로그램이 어깨관 절의 통증, 관절가동범위, 우울증 그리고 삶의 질에 미치는 영향을 알아보고, 향후 중년 여성의 수술 후 기능적 회복뿐만 아니라 우울증 과 삶의 질 개선에 대한 임상적 근거와 기초자료를 제공하고자 한다.

\section{연구 방법}

\section{1. 연구대상}

본 연구는 성남시에 위치한 B 병원에서 자기공명영상(MRI)을 통해 돌림근띠 파열이 확인되어 정형외과 전문의로부터 관절경 돌림근띠 봉합술을 받은 40-59세의 중년 여성 환자 20 명을 대상으로 하였다. 본 연구의 대상자 조건은 다음과 같다. 1) 어깨 돌림근띠 파열을 진단받 고 수술 후 4-6주 이내인 환자로 출혈, 감염 등의 합병증이 없는 자, 2) 수술 후 치료적 마사지와 가정 운동 프로그램을 받은 경험이 없는 자, 3) 의식이나 감각 장애가 없는 자로 교육 내용을 이해하고 의사소통 이 가능한 자, 4) 어깨 외에 다른 부위에 근골격학적, 신경학적 질환의 병력이 없는 자이다. 모든 대상자들은 8 주간 가정운동프로그램을 적 용하면서 치료적 마사지를 병행한 실험군 $(\mathrm{N}=10)$ 과 가정운동프로그 램만을 적용한 대조군 $(\mathrm{N}=10)$ 에 무작위로 배정받았다. 실험군 10 명 중 1 명은 개인적인 사유로 모든 실험을 완료하지 못하였기 때문에 본 연구에서 제외되었다. 모든 대상자들은 연구의 목적과 의도를 이해 하고 자발적으로 연구 동의서에 서명한 후 연구에 참여하였다.

\section{2. 측정도구 및 방법}

1) 시각상사척도(visual analogue scale, VAS)

중재 전·후 어깨부위의 통증 변화를 측정하기 위해 임상에서 광범위 하게 사용되는 주관적 통증 평가 도구인 시각상사척도를 사용하였 다. ${ }^{17}$ 본 연구에서 사용한 VAS는 $10 \mathrm{~cm}$ 수평선상의 왼쪽 끝을 0 (통증 없음), 오른쪽 끝을 10 (견디기 힘든 통증)으로 설정하여 대상자가 느 끼는 통증의 강도를 본인이 직접 표시하도록 하였다. VAS의 검사-재 검사 신뢰도는 $r=0.95$ 로 높은 수준의 신뢰도를 가진 평가도구이다. ${ }^{17}$

\section{2) 능동 관절가동범위(active range of motion, $\mathrm{AROM}$ )}

중재 전·후 어깨관절의 능동 관절가동범위 변화를 측정하기 위해 각 도계(JAMAR Stainless steel goniometer, Preston, USA)를 사용하였다. 어깨관절 굽힘은 팔을 자연스럽게 옆으로 두고 똑바로 선 자세에서 어깨뼈 봉우리의 부리돌기를 축으로 고정자는 겨드랑이의 중앙선에 
두고 이동자는 위팔뼈의 중심선에 일치한 상태에서 측정하였으며, 어깨관절 벌림은 어깨뼈 봉우리의 앞쪽을 축으로 고정자는 겨드랑 이 아래에 두고 이동자는 위팔뼈의 중심선에 일치시켜 측정하였다. 마지막으로 어깨관절 가쪽돌림은 팔꿈치를 $90^{\circ}$ 굽힘 한 상태에서 자 뼈의 팔꿈치머리 아래를 축으로 고정자는 어깨와 수직으로 두고 이 동자는 아래팔의 중심선에 일치시켜 측정하였다. $\mathrm{AROM}$ 측정은 각각 의 동작 수행 시 통증이 나타나거나 가동범위가 제한되는 지점에서 동작을 멈추도록 하였으며 총 3 회 측정 후 평균값을 사용하였다.

\section{3) 자기보고식 우울 척도(Zung's self-rating depression scale, SDS)}

Zung의 자기보고식 우울 척도(SDS)는 심리적인 우울 성향 정도를 측 정하는 10 개의 문항과 생리적인 우울 성향 정도를 측정하는 8 개의 문 항 그리고 전반적인 우울정도를 측정할 수 있는 2 개의 문항으로 총 20 개의 문항으로 구성되어 있다. 각 항목마다 '거의 그렇지 않다(1점), 때 때로 그렇다(2점), 자주 그렇다(3점), 거의 항상 그렇다(4점) 중 한 가지 로 응답할 수 있는 Likert 척도로 구성된다.SDS 점수는 각 항목의 점수 를 합산하여 20-80점의 범주로 평가되며, 49점 이하는 정상 범위, 50-59 점은 경증 우울증, 60-69점은 중등도 우울증, 70점 이상은 중증 우울증 으로 분류된다. 본 연구에 사용된 한국어판은 Cronbach 알파 값이 0.847 , 검사-재검사상관관계가 0.820 로 우수한 신뢰도를 보인다.18

\section{4) WHO Quality of Life-BREF (WHOQOL-BREF)}

중재 전. 후 삶의 질 변화를 평가하기 위하여 세계보건기구에서 개발 한 것을 국내에서 한국형 버전으로 축약한 WHOQOL-BREF를 사용 하였다. ${ }^{19} \mathrm{WHOQOL-BREF}$ 는 전반적인 삶의 질과 건강에 대한 2 개의 문항과 신체적 건강 영역(7문항), 심리적 건강 영역(5문항), 사회적 관 계 영역(3문항), 환경 영역(7문항)을 포함하여 총 24 개 문항으로 구성 되어 있다. 각 문항의 점수는 5 점 척도로 '전혀 아니다는 1점, '약간 그 렇다'는 2점, '그렇다'는 3점, '많이 그렇다'는 4점, '매우 많이 그렇다는 5 점으로 구성되어 있고 문항 중 일상생활치료(문항 3 번), 통증과 불편 감(문항 4번), 부정적 감정(문항 24번) 등은 매우 많이 그렇다가 가장 부정적인 반응으로 되어 있어 합산 시 역환산 하도록 한다. 총점의 범 위는 최저 24 점에서 최고 120 점이며 점수가 높을수록 건강관련 삶의 질이 좋음을 의미한다. WHOQOL-BREF는 WHOQOL과 높은 상관 관계(0.89-0.95)와 내적 일치도(0.66-0.84)를 보여주고 있으며, 근골격 계 질환을 가진 환자들을 대상으로 삶의 질을 측정하기 위해 임상에 서 많이사용되고 있다.

\section{3. 실험 절차}

본 연구에서 실험군과 대조군 모두 중재 전 숙련된 물리치료사에 의 해 어깨 통증 및 능동 관절가동범위와 우울증, 삶의 질을 측정하였으
며, 사전 검사 후 가정운동프로그램 중재를 1 회 30 분, 매일 3 회, 8 주간 적용하였다. 실험군은 가정운동프로그램을 적용하면서 치료적 마사 지를 주 2 회씩 8 주간 총 16 회를 시행하였다. 대조군은 실험군과 동일 하게 가정운동프로그램을 적용하면서 열, 전기치료를 포함한 기본 물리치료를 주 2 회씩 회당 30 분, 8 주간 시행하였다. 모든 대상자는 중 재 전 가정운동프로그램에 대한 교육을 받았다. 가정운동프로그램 은 어깨 돌림근띠 파열에 관한 의학적 정보와 올바른 생활습관, 통증 예방 및 자가 운동 방법에 대한 내용으로 구성하여 책자를 제공하였 고 숙련된 물리치료사가 교육을 실시하였다. 가정운동프로그램의 원활한 수행을 위해 대상자에게 제공한 책자 후면에 운동수행 후 체 크하도록 하였으며, 병원에 내원하였을 때 지속적으로 확인하고 잘 못된 동작에 대해 재교육을 실시하였다. 중재 후 사후 검사는 사전 검 사와동일하게 측정하였다.

\section{1) 치료적 마사지}

본 연구에서 적용한 치료적 마사지는 통증을 경감시키고 기능장애 를 개선하기 위한 목적으로 연부조직에 수기 조작을 가하는 James의 치료적 마사지 프로토콜을 연구자가 본 연구 대상자에 맞게 어깨부 위 및 위팔부위의 근육과 인대 등에 적용할 수 있도록 일부 수정 보 완한 것으로 구성하였다. ${ }^{20}$ 치료적 마사지는 어깨주위 관절의 과부하 와 피로 및 손상에 직접적으로 관여하는 위등세모근, 큰가슴근, 어깨 세모근, 위팔두갈래근, 어깨올림근, 마름근, 위가시근, 아래가시근 등 에 교차섬유 마찰법(cross-fiber friction), 압박법(compression), 집기 촉 진법(grips palpation)을 시행하였다. 교차섬유 마차법은 근육조직, 인 대 또는 힘줄의 병변 부위 그리고 섬유화된 부위를 직각 방향으로 앞, 뒤로 마찰을 일으키는 방법이며, 압박법은 근육의 표면에 대해서 똑 바로 누르는 압을 말하고, 집기 촉진법은 엄지와 집게 또는 세 번째 손가락의 바깥쪽 면을 이용하여 조직을 잡는 방법을 말한다(Figure 1). 어깨 주위 근육에 대한 치료적 마사지는 회당 총 30 분을 적용하였 으며, 숙련된 전담 치료사에 의해 실시되었다.

\section{2) 가정운동프로그램}

본 연구에서 적용한 가정운동프로그램은 B 병원에서 관절경 돌림근 띠 복원술 후 시행되는 자가-스트레칭 운동과 능동보조운동 프로그 램을 적용하였다. 가정운동프로그램은 수술 후 6 주부터 1단계를 시 작으로 2 주씩 총 4 단계, 8 주 동안 시행하였고, 1 단계 운동은 바로 누 운 자세에서 어깨관절 굽힘과 수평모음, 옆으로 누운 자세에서 어깨 관절 가쪽돌림과 안쪽돌림, 2 단계 운동은 앉은 자세에서 수평모음 과 벽에 팔을 대고 가쪽돌림, 수건을 이용한 안쪽돌림, 어깨관절 굽 힘을 시행하였다(Figure 2). 3 단계 운동은 선 자세에서 T-bar를 이용한 어깨관절 굽힘, 가쪽돌림, 수평모음, 안쪽돌림을 시행하였고, 4 단계 운 

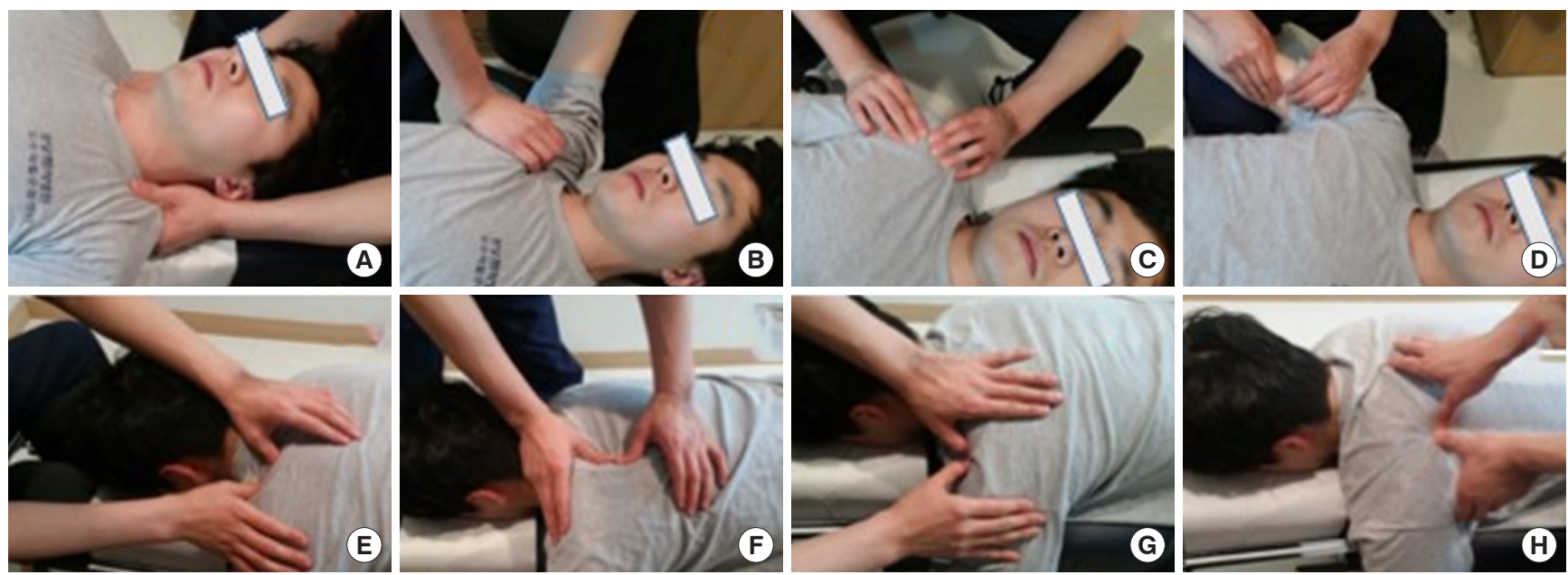

Figure 1. Therapeutic massage program. (A) upper trapezius grips, (B) pectoralis major grips, (C) deltoid grips, (D) biceps grips, (E) levator scapulae cross-fiber friction, (F) rhomboid cross-fiber friction, (G) supraspinatus compression, (H) infraspinatus compression.
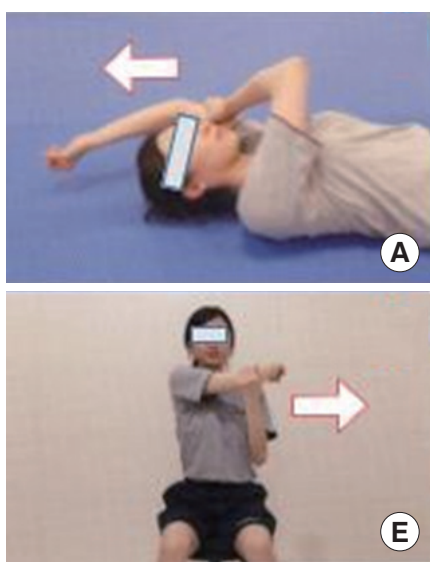
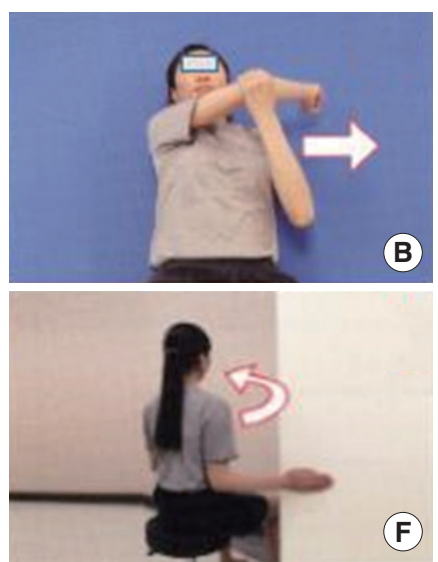
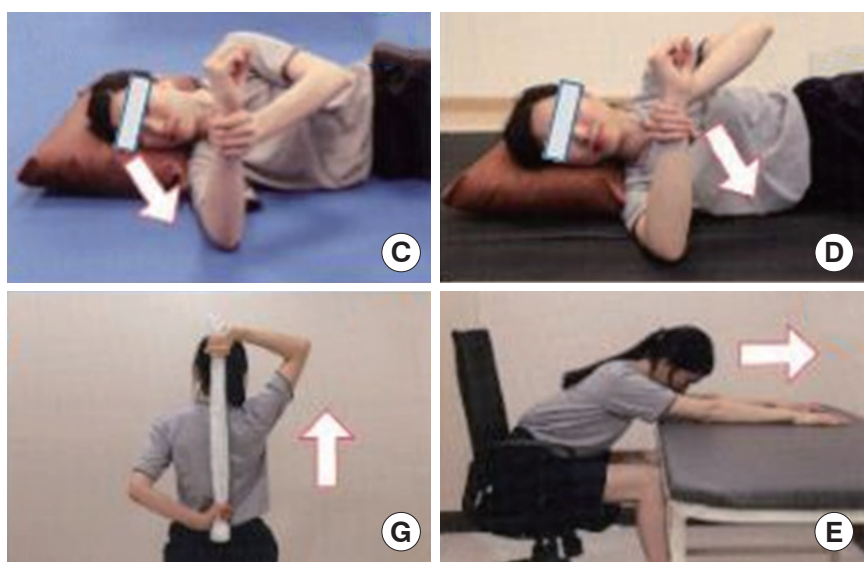

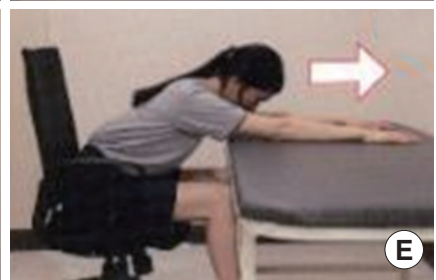

Figure 2. Home exercise program phase 1, 2. (A) forward flexion, (B) horizontal adduction, (C) side external rotation, (D) side internal rotation, (E) sitting horizontal adduction, (F) ckc extenal rotation, $(G)$ internal rotation with extension, $(H)$ forward flexion.
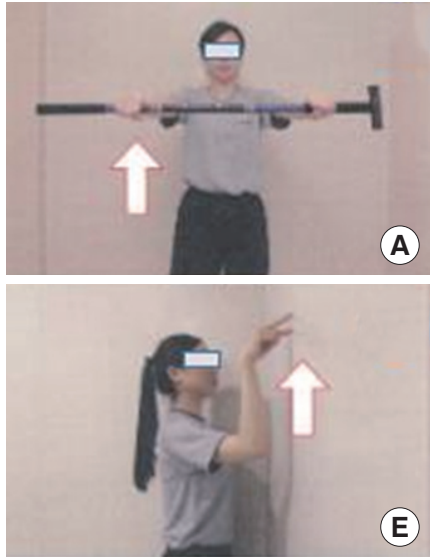

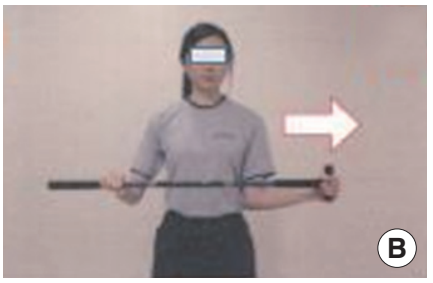

(B)

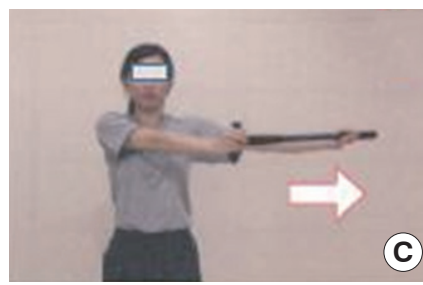

(F)

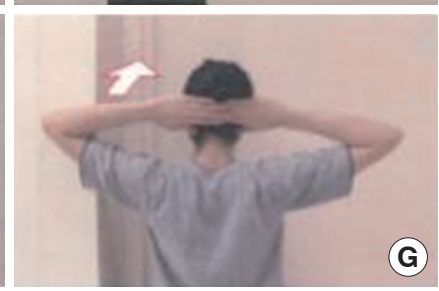

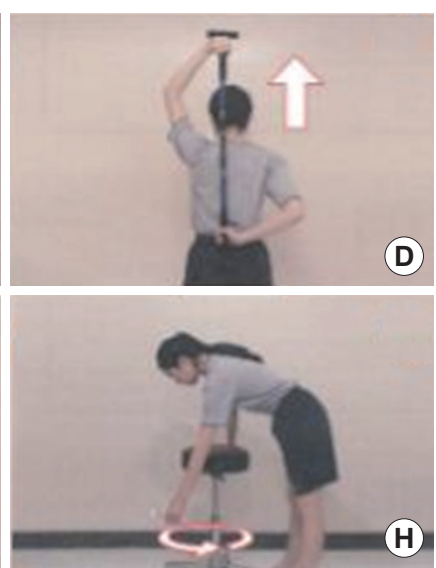

Figure 3. Home exercise program phase 3, 4. (A) T-bar forward flexion, (B) external rotation, (C) horizontal adduction, (D) internal rotation with extension, (E) active assistive forward flexion (F) abduction, (G) pectoralis stretching, (H) pendulum movement.

동에서는 능동보조운동으로 선 자세에서 벽을 이용한 어깨관절 굽힘, 벌림, 큰가슴근 스트레칭, 어깨 진자운동으로 구성되어 있다(Figure 3).
운동의 최대범위는 관절 끝 범위에서 통증이 느껴지는 범위 하에서 약간의 불편함이 느껴질 때까지 10 초정도 유지하도록 하였고, 모든 
운동은 대상자의 운동 수행능력을 고려하여 초기에는 중력의 영향 을 배제하여 시행하였으며, 후기에는 T-bar를 이용하여 최대 스트레 칭이 일어나도록 강도를 조정하였다. 가정운동프로그램은 1 세트 10 회, 3 세트, 세트 간 휴식시간은 10 초로 적용하였으며, 숙련된 전담 치 료사에 의해 교육되었으며, 수행능력을 평가하여 단계가 조정되었다.

\section{4. 자료분석}

모든 자료는 Window용 SPSS program version 22.0 (SPSS, Chicago, IL, USA)을 이용하여 기술 통계를 산출하였으며, 자료에 대한 정규성 검 정을 위해 Shapiro-Wilk 검정을 실시하여 모든 자료의 정규 분포를 확 인하였다. 대상자의 일반적 특성은 독립표본 $\mathrm{t}$ 검정(Independent t-test) 을 실시하여 동질성 검증을 실시하였다. 실험군과 대조군에서 각각 중재 전과 후 VAS, AROM, SDS, WHOQOL-BREF의 변화를 비교하기 위하여 Wilcoxon signed rank test를 실시하였다. 또한 두 집단 간에 측 정 변수들의 중재 전후 변화량의 평균값을 비교하기 위하여 Mann Whitney U-test를 실시하였다. 통계학적 유의수준은 $\alpha=0.05$ 로 설정하 였다.

Table 1. General characteristics of subjects

\begin{tabular}{lrrc}
\hline & $E G(n=9)$ & $C G(n=10)$ & $p$ \\
\hline Age $(\mathrm{yr})$ & $55.1 \pm 4.3$ & $56.2 \pm 3.6$ & 0.560 \\
Height $(\mathrm{cm})$ & $155.4 \pm 3.7$ & $156.5 \pm 3.3$ & 0.241 \\
Weight $(\mathrm{kg})$ & $57.4 \pm 7.5$ & $61.1 \pm 5.2$ & 0.230 \\
\hline
\end{tabular}

Mean \pm SD

EG: Experimental group, CG: Control group.

\section{결 과}

연구 대상자의 일반적 특성은 Table 1과 같다. 나이, 키, 몸무게에 대한 집단 간 비교 결과 통계적으로 유의한 차이가 없었다 $(\mathrm{p}>0.05)$. 중재 전후 두 집단의 VAS, AROM, SDS, WHOQOL-BREF의 변화를 비교한 결과는 Table 2와 같다. 두 집단의 VAS 점수는 중재 전에 비해 중재 후 통계적으로 유의하게 감소하였다 $(\mathrm{p}<0.05)$. 중재 전후 VAS 점수의 변 화량에 대한 집단 간 비교 결과 실험군에서 더 큰 감소를 보였지만 통 계적으로 유의한 차이가 없었다( $\mathrm{p}>0.05)$. 어깨관절 굽힘의 AROM은 두 집단 모두 중재 후 통계적으로 유의하게 증가하였으며 $(\mathrm{p}<0.05)$, 집 단 간 비교 결과 실험군이 대조군에 비해 유의한 증가를 보였다 $(\mathrm{p}<0.05)$. 어깨관절 벌림과 가쪽돌림의 AROM에서는 두 집단 모두 중재 후 통계적으로 유의하게 증가하였으나 $(\mathrm{p}<0.05)$, 집단 간 유의한 차이는 없었다 $(\mathrm{p}>0.05)$. SDS 및 WHOQOL-BREF 점수에서는 두 집단 모두 중재 후 통계적으로 유의하게 증가하였으며 $(\mathrm{p}<0.05)$, 집단 간 비 교 결과 실험군이 대조군에 비해 유의한 증가를 보였다 $(\mathrm{p}<0.05)$.

\section{고 찰}

중년 여성에게서 돌림근띠 파열은 어깨주위의 통증과 일상생활활동 뿐만 아니라 심리적인 장애를 일으키는 흔한 질병 중 하나로 보존적 인 치료에도 호전을 보기가 어려운 경우 관절경 돌림근띠 복원술이 보편적으로 시행된다. ${ }^{21}$ 하지만 수술 후 돌림근띠의 피로도 증가와 근 력 약화로 인한 능동 움직임의 제한으로 어깨 기능회복 및 환자의 만 족도에 영향을 줄 수 있다.22 따라서 수술 후 초기 재활에서는 돌림근

Table 2. Comparison of outcome measures (change scores of within-group and between-group comparison)

\begin{tabular}{|c|c|c|c|c|c|c|}
\hline \multirow{2}{*}{ Outcome measures } & \multirow{2}{*}{ Group } & \multicolumn{3}{|c|}{ Within-group comparison $^{+}$} & \multicolumn{2}{|c|}{ Between-group comparison $^{\dagger}$} \\
\hline & & Pre-test & Post-test & $p$ & Post-pre difference & $p$ \\
\hline \multirow[t]{2}{*}{ VAS (score) } & EG & $7.88 \pm 1.96$ & $1.88 \pm 0.92$ & $0.008^{*}$ & $-6.00 \pm 2.06$ & 0.549 \\
\hline & CG & $8.60 \pm 1.26$ & $2.90 \pm 1.44$ & $0.005^{*}$ & $-5.70 \pm 1.15$ & \\
\hline \multirow[t]{2}{*}{ Sh flex AROM (degree) } & EG & $91.66 \pm 30.61$ & $158.88 \pm 12.69$ & $0.008^{*}$ & $67.22 \pm 23.33$ & $0.017^{*}$ \\
\hline & CG & $102.00 \pm 14.75$ & $146.00 \pm 9.66$ & $0.004^{*}$ & $44.00 \pm 15.05$ & \\
\hline \multirow[t]{2}{*}{ Sh abd AROM (degree) } & EG & $60.55 \pm 12.69$ & $137.22 \pm 35.45$ & $0.008^{*}$ & $76.66 \pm 40.54$ & 0.182 \\
\hline & CG & $67.00 \pm 11.59$ & $131.50 \pm 18.56$ & $0.005^{\star}$ & $64.50 \pm 17.37$ & \\
\hline \multirow[t]{2}{*}{ Sh er AROM (degree) } & EG & $20.55 \pm 6.34$ & $53.88 \pm 16.35$ & $0.008^{*}$ & $33.33 \pm 16.39$ & 0.780 \\
\hline & CG & $23.00 \pm 6.74$ & $53.50 \pm 13.95$ & 0.007 & $30.50 \pm 14.61$ & \\
\hline \multirow[t]{2}{*}{ SDS (score) } & EG & $46.88 \pm 5.15$ & $33.33 \pm 5.53$ & $0.008^{*}$ & $-13.55 \pm 6.72$ & $0.013^{*}$ \\
\hline & CG & $43.00 \pm 5.63$ & $35.70 \pm 4.85$ & $0.005^{*}$ & $-7.30 \pm 4.24$ & \\
\hline \multirow[t]{2}{*}{ WHOQOL-BREF (score) } & EG & $71.77 \pm 10.03$ & $84.33 \pm 6.36$ & $0.008^{*}$ & $12.55 \pm 6.82$ & $0.035^{*}$ \\
\hline & CG & $74.80 \pm 5.11$ & $82.20 \pm 3.19$ & $0.005^{*}$ & $7.40 \pm 2.45$ & \\
\hline
\end{tabular}

Mean \pm SD.

EG: Experimental group, CG: Control group, VAS: Visual analogue scale, Sh flex AROM: Shoulder flexion active range of motion, Sh abd AROM: Shoulder abduction active range of motion, Sh er AROM: Shoulder external rotation active range of motion, SDS: Self-rating depression scale, WHOQOL-BREF: WHO Quality of Life-BREF.

${ }^{*} \mathrm{p}<0.05,{ }^{+}$Analysed by paired t-test, ${ }^{\star}$ Analysed by independent t-test. 
띠 힘줄을 보호하면서 어깨관절의 유착을 방지하고 통증 감소 및 기 능회복을 위해 가동범위를 증가시키는 것이 중요하다.

본 연구에서는 관절경 돌림근띠 복원술을 시행한 중년 여성 환자 에게 수술 후 가정운동프로그램과 치료적 마사지 적용이 통증, 어깨 관절 능동가동범위, 우울증 및 삶의 질에 어떠한 영향을 미치는지 알 아보았다. 이를 위해 가정운동프로그램과 치료적 마사지를 병행한 실험군과 가정운동프로그램만을 적용한 대조군으로 구분하여 8 주 간 중재 후 수술한 어깨의 기능적 측면과 심리적 측면의 변화를 비교 하였다. 연구 결과 모든 집단에서 중재 후 통증, 어깨관절 능동가동범 위, 우울증, 삶의 질의 개선이 나타났다. 하지만 중재 전후 변화량의 집단 간 비교에서는 어깨관절 굽힘의 능동가동범위, 우울증, 삶의 질 에서 유의한 차이가 나타났다. 이는 수술 후 가정 운동 프로그램뿐만 아니라 치료적 마사지를 병행하였을 때 팔을 들어 올리는 범위와 우 울증 및 삶의 질을 더 크게 개선시키는 것을 의미한다.

연구 결과 집단 내 비교에서 두 집단 모두 어깨 통증이 유의하게 감 소하였으며, 어깨관절 능동가동범위가 유의하게 증가하였다. 선행연 구에서 $\mathrm{Cho}^{23}$ 는 12 주간의 자가-스트레칭운동과 스포츠마사지 모두 어깨 통증 및 어깨 유연성을 개선시켰으며, 스포츠마사지를 실시하 였을 때 효과가 더 빠르게 나타났다고 보고하였다. Jung ${ }^{24}$ 은 어깨봉우 리성형술을 받은 환자를 대상으로 3 주간 스포츠마사지 및 스트레칭 프로그램을 적용한 결과 염증수치를 반영하는 C-반응성 단백 수치 와 적혈구 침강 속도가 감소하였다고 보고하였다. 이는 수술 후 적용 하는 마사지와 스트레칭은 피부나 근육의 혈액순환을 향상시키고 신진대사를 높여 산소나 영양분의 공급을 촉진함으로써 수술로 인 한 염증을 줄이고 통증을 완화하는데 긍정적인 영향을 줄 수 있다는 것을 의미한다. 또한 $\mathrm{Jang}^{25}$ 은 어깨통증 환자에 대한 치료적 마사지와 어깨관절 안정화 운동의 복합적용이 통증 개선에 효과적이라고 보 고하였으며, $\mathrm{Kwag}^{26}$ 은 기능적 마사지와 신장운동을 적용한 도수치료 는 가정운동만을 수행하는 것보다 빠른 통증 감소와 관절가동범위 향상에 영향을 준다고 보고하여 본 연구 결과와 일치한다.

집단 간 비교에서는 실험군의 어깨관절 굽힘, 벌림, 가쪽돌림에서 더 큰 능동 가동범위를 보였지만 굽힘에서만 유의한 차이가 있었다. 돌림근띠 봉합술 이후 관절주머니의 단축으로 인해 어깨관절의 수 동 움직임 제한과 근약화로 인한 능동 움직임의 제한이 흔히 발생하 며, 움직임 수행 시 근육작용의 불균형으로 인한 보상적 움직임으로 이차적인 압박이나 장력이 가해질 수 있다. ${ }^{27} \mathrm{Paul}^{28}$ 의 연구에서는 어 깨통증 환자를 대상으로 4 주 동안 운동치료만 적용한 집단보다 운동 치료와 연부조직 마사지를 병행한 집단이 어깨관절 굽힘, 벌림에서 더 큰 관절가동범위 증가를 보였으며, Yeun ${ }^{29}$ 의 어깨관절 가동범위에 관한 마사지 치료의 체계적 고찰 및 메타분석 연구에서는 마사지가 특히 어깨관절의 굽힘과 벌림의 가동범위를 향상시키는데 효과적이
라고 보고하였다. 이는 스트레칭운동과 치료적 마사지가 역학적, 신 경생리학적으로 유착된 관절과 단축된 연부조직에 작용하여 연골 기질 및 활액 사이 흐름을 증가시키고, 관절주머니 교원섬유의 재배 열과 조직의 유리화를 통해 과도한 위쪽 등세모근의 억제와 앞톱니 근과 짝을 이루는 위등세모근 및 아래등세모근의 적절한 작용을 유 도하여 어깨뼈의 위쪽돌림이 원활하게 이루어졌기 때문이다. 또한 $\mathrm{Kim}^{30}$ 의 돌림근띠 봉합술 후 재활에 관한 연구에서는 중파열 이하의 작은 파열의 경우 수술 후 4 주 동안 진자운동, 보조적 수동운동에서 보조적 능동운동으로 진행하고 4 주에서 6 주 사이에는 스트레칭을 시행하며 6 주에서 12 주까지는 근력강화운동, 12 주에서 6 개월 사이의 기간에는 점차 스포츠활동과 직업 활동에 복귀하도록 한다.

기존의 관절경 돌림근띠 복원술 후 재활에 관한 연구들에서 사용 된 평가 도구들은 어깨관절의 기능적 평가와 같은 신체적 평가에 국 한되어 있으며 수술 후 우울증이나 삶의 질과 같은 심리적 평가에 관 한 연구는 다소 부족하다. 또한 어깨손상 환자의 삶의 질은 통증 및 기능장애와상당한 관련이 있지만 이차적으로 심리적인 요인도 많은 영향을 준다. 수술 후 신체적 평가 결과와는 달리 불만족을 호소하는 환자가 있으며 실제 환자가 느끼는 만족도를 정확하게 대변하지 못하 기 때문에 환자의 심리적, 사회적 요소가 포함된 우울 및 삶의 질을 모두 평가하는 것은 중요하다. ${ }^{31}$ 특히, 중년여성은 갱년기로 인한 정서 적 변화로 가장 많이 나타나는 것이 우울증이며, 단순히 호르몬 불균 형에 기인하기 보다는 질환으로 인한 신체적 변화에 따른 정서심리 적 요인과 생활양상의 변화에 더 많은 영향을 받는 것으로 알려져 있 다. ${ }^{32}$ 최근 우울증상이 있을 경우, 돌림근띠 파열과 수술에 높은 위험 과 연관성이 있다고 보고되고 있으며,33 본 연구 결과 관절경 수술 후 우울증 및 삶의 질에서 두 집단 모두 유의하게 개선되었고, 치료적 마 사지를 병행한 집단에서 더 큰 효과가 나타났다. Yang ${ }^{34}$ 의 연구에서 는 만성 통증 여성에게 10 주간의 마사지 중재 후 우울지수의 감소와 삶의 질이 증가하였고, $\mathrm{Jin}^{35}$ 의 연구에서는 마사지 프로그램으로 진행 된 도수치료 적용이 일자목 환자의 우울감소와 삶의 질의 증가에 효 과적이라고 하였기에 본 연구 결과와 일치한다. 이는 치료적 마사지 를 통한 근육의 이완과 순환증진이 심리적 긴장과 불안, 우울 및 스 트레스를 감소시키고 치료사와 환자 간의 신뢰관계를 형성함으로써 나타난 결과라 생각된다. 또한, 우울지수가 낮아질수록 삶의 질이 증 가하는 음의 상관관계에 있으므로, ${ }^{35}$ 치료적 마사지 적용이 우울지수 를 감소시켜 삶의 질 개선에 영향을 주었을 것이라 생각된다.

본 연구는 관절경 돌림근띠 복원술 후 자가-스트레칭운동을 포함 한 가정운동프로그램과 치료적 마사지를 결합한 중재가 어깨 통증 및 어깨관절 굽힘의 기능적 회복을 촉진하고 심리적인 우울증 및 삶 의 질 개선을 가져올수 있음을 보여주었다. 수술 후 재활에서 보존적 치료 이외의 지속적인 가정운동프로그램은 초기 어깨관절 가동범 
위 회복에 긍정적인 영향을 주며, 치료적 마사지는 어깨기능 향상뿐 만 아니라 우울증이나 삶의 질과 같은 심리적 요인을 개선함으로써 치료의 만족도를 높여 주기 때문에 추후 임상적 중재 프로그램을 구 성함에 있어 활용될 수 있을 것이다. 본 연구의 제한점은 파열된 범위 로 구분하지 못한 부분과 표본의 크기가 적어 연구의 결과를 일반화 하는데 어려움이 있으며, 중재 프로그램에 근력강화운동을 포함하 지 않아 초기 치료 효과만을 확인하였다. 또한 가정운동프로그램과 치료적 마사지 중재 후 통증, 관절가동범위, 우울과 삶의 질에 대한 상관관계를 확인하지 못한 제한점이 있다. 앞으로의 연구는 본 연구 의 제한점들을 보완하여 관절경 돌림근띠 복원술 이후 다양한 유형 의 가정운동프로그램을 장기적으로 적용하고 심리적 문제를 개선하 기 위한 효과적인 중재 방법에 관한 연구가 필요할 것이라 생각된다.

\section{ACKNOWLEDGEMENTS}

본 연구는 이영민의 2015년도 석사학위 논문을 바탕으로 작성하였음.

\section{REFERENCES}

1. Seitz AL, McClure PW, Finucane S et al. Mechanisms of rotator cuff tendinopathy: intrinsic, extrinsic, or both? Clin Biomech (Bristol, Avon). 2011;26(1):1-12

2. Minagawa $\mathrm{H}$, Yamamoto $\mathrm{N}$, Abe $\mathrm{H}$ et al. Prevalence of symptomatic and asymptomatic rotator cuff tears in the general population: from massscreening in one village. J Orthop. 2013;10(1):8-12.

3. Koo HJ, Cho CH, Jung SW. Psychological status and quality of life in patients with rotator cuff disease. J Korean Soc Biol Ther Psychiatry. 2011; 17(1):96-103.

4. Kim JY, Chun CH, Kim JW et al. Clinical results of arthroscopic transtendon suture technique of partial articular surface tendon avulsion lesion. Clin Should Elbow. 2011;14(2):165-71.

5. Jo YH, Lee KH, Kim SJ et al. National trends in surgery for rotator cuff disease in Korea. J Korean Med Sci. 2017;32(2):357-64.

6. Cho NS, Hwang JC, Rhee YG. Clinical results of arthroscopic repairin full-thickness rotator cuff tears. J Korean Orthop Assoc. 2006;41(5):85764.

7. Cho HS. An analytic study on nursing diagnosis for elderly patients with total knee replacement. Catholic University of Pusan. Dissertation of Master's Degree. 2010.

8. Thigpen CA, Shaffer MA, Gaunt BW et al. The american society of shoulder and elbow therapists' consensus statement on rehabilitation following arthroscopic rotator cuff repair. J Shoulder Elbow Surg. 2016; 25(4):521-35.

9. Kim TS. Impact of chronic shoulder pain and improvement of motion range through therapeutic, healing massage program. Mokwon University. Dissertation of Master's Degree. 2013.

10. Ham JY. Effects of therapeutic massage intervention on pain of patients with unilateral total knee replacement arthroplasty. Kwandong Univer- sity. Dissertation of Master's Degree. 2012.

11. Cho CH, Jung SW, Son ES et al. Sleep status and quality of life in patients with frozen shoulder. J Korean Orthop Assoc. 2012;47(3):205-10.

12. Shin HS, Lee KS. Effects of combined resistance exercise on range of motion (ROM), grip strength and pain in middle-aged women with shoulder disorder. Korean J Sport Sci. 2006;15(1):569-77.

13. Yoon HY, Choi JD. Effects of low-intensity scapular stabilization exercise in arthroscopic shoulder surgery patients. J Kor Phys Ther. 2012;24(3): 229-34.

14. Lee DY, Kim SG. The association between health-related quality of life and depression on activity restriction in osteoarthritis: a cross-sectional study. J Kor Phys Ther. 2020:32(6):329-34.

15. Jeon HC, Kim GW. Effectiveness of global postural reeducation compared to segmental stretching on pain, disability, and QOL of subjects with neck and shoulder pain. J Kor Phys Ther. 2017:29(1):7-15.

16. Kwak KI, Choi BJ, Yoon YJ. Effects of home exercise program and manual therapy on shoulder function and quality of life in patients with adhesive capsulitis. J Kor Phys Ther. 2016:28(5):286-91.

17. Wagner DR, Tatsugawa K, Parker D et al. Reliability and utility of a visual analog scale for the assessment of acute mountain sickness. High Alt Med Biol. 2007;8(1):27-31.

18. Lee JH. Development of the Korean form of Zung's self-rating depression scale. Yeungnam Univ J Med. 1995;12(2):292-305.

19. Min SK, Lee CI, Kim KI et al. Development of Korean version of WHO quality of life scale abbreviated version (WHOQOL-BREF). J Korean Neuropsychiatr Assoc. 2000;39(3):571-9.

20. James HC. Basic clinical massage therapy: integrating anatomy and treatment. New York, Lippincott Williams \& Wilkins, 2004:21-22.

21. Choi CH, Um DH, Kim SG. Pain \& motion recovery patterns after rotator cuff repair according to tear size. J Korean Orthop Assoc. 2005;40 (7):826-31.

22. Namdari S, Green A. Range of motion limitation after rotator cuff repair. J Shoulder Elbow Surg. 2010;19(2):290-6.

23. Cho CH, Lim YJ. When does the quality of life improve after rotator cuff repair? J Korean Orthop Assoc. 2013;48(4):281-9.

24. Jung HY. Effects of the post-operation sports massage and stretching program on the inflammation index in patients undergoing acromioplasty. The Korean Journal of Physical Education. 2013;52(5):765-72.

25. Jang JH. The effect of complex application, therapeutic massage and shoulder stabilization exercise, on pain and grip strength. Daegu Haany University. Dissertation of Master's Degree. 2017.

26. Kwag KI, Seo EK, Kim TY. The effects of group exercise, manual therapy and home exercise on pain, range of motion and function in patient with adhesive capsulitis. J Kor Phys Ther 2016:28(2):101-5.

27. McKee MD, Yoo DJ. The effect of surgery for rotator cuff disease on general health status. Results of a prospective trial. J Bone Joint Surg Am. 2000;82(7):970-9.

28. Paul VDD, Paulo F, Kathryn R. Is soft tissue massage an effective treatment for mechanical shoulder pain? a study protocol. J Man Manip Ther. 2010;18(1):50-4.

29. Yeun YR. Effectiveness of massage therapy on the range of motion of the shoulder: a systematic review and meta-analysis. J Phys Ther Sci. 2017; 29(2):365-9.

30. Kim JH. Rehabilitation of rotator cuff repair. J Korean Arthrosc Soc. 
2008;12(2):82-6.

31. Yoon JP, Oh JH, Min WK et al. What do the patients want and worry in korean patients who undergo arthroscopic rotator cuff surgery? Clin Orthop Surg. 2012;4(4):278-83.

32. Jee YJ, Kim KN. Factors affecting quality of life in middle-age female depressed patient. AJMAHS. 2018;8(9):715-24.

33. Kuo LT, Chen HM, Yu PA et al. Depression increases the risk of rotator cuff tear and rotator cuff repair surgery: a nationwide population-based study. PloS One. 2019;14(11):e0225778.

34. Yang IS, Lim DH. The effect of manipulative therapy of blind masseurs on pain, sleep, depression, quality of life in adult women with chronic pain. J Korea Soc Beauty Art. 2020;21(1):217-28.

35. Jin CW. The effect of manual therapy on pain, depression and quality of life in patients with cervical hypolordosis. Sungshin University. Dissertation of Master's Degree. 2015. 